\title{
A method for identifying individual subjects within a group of fish
}

\author{
TOM VEZIE and R. CHRIS MARTIN \\ University of Missouri-Kansas City, Kansas City, Missouri 64110
}

\begin{abstract}
To identify individuals within a group of fish, several dyes were tested for the distinctiveness of marking, duration of marking, toxicity, and effects upon individual and social behavior. Several of the dyes, including common food coloring, proved to be effective.
\end{abstract}

When observing animal groups, the desirability of identifying individuals soon becomes apparent. This identification problem has been solved by tags, collars, or leg bands with some species, but to date there has not been a satisfactory solution when the subject species are small fish. Perhaps this is one reason that much fish research has been limited primarily to the study of individuals, pairs, or groups (Braddock, 1949; Keenleyside, 1955; Shaw, 1960). Research on the behavior of individuals within the group has been largely ignored.

To attack this problem of identification, Ss were injected with several kinds of dyes; the effectiveness of the dyes for marking purposes, the effect of the dye on the behavior of the $\mathrm{S}$, and whether the fish was ostracized from the group were observed.

\section{METHOD}

\section{Subjects}

Thirtyeight fathead minnows (Pimephales promelas) obtained from a bait shop were the Ss. Ss ranged in size from 6 to $10 \mathrm{~cm}$.

\section{Apparatus}

A large Plexiglas tank holding approximately 100 gal of water was used to house the Ss (further details of apparatus may be found in Martin \& Deemer, 1971). This tank was constructed so that it was easily divided into compartments to segregate Ss while maintaining similar environmental conditions.

Disposable syringes used to inject dyes were fitted with 27-ga 1-in. needles. Ten different dye materials were tested for marking capability. Sterile water was used as a control substance.

The 10 dye materials employed were as follows: (1) methylene blue for injection, U.S.P. (1\%), (2) green leaf shade (3\%), (3) saffron red, (4) gentian violet (2\%), (5) Imferon (an iron supplement) at a strength of $50 \mathrm{mg} / \mathrm{ml},(6)$ a special mixtu re of toluidine blue solution $(1 \%)$ in distilled water $(15 \mathrm{ml})$ and glycerine $(15 \mathrm{ml})$ prepared in a pharmacy, (7) common red liquid food coloring (Schilling), (8) common blue liquid food coloring (Schilling), (9) common yellow liquid food coloring (Schilling), and (10) common green liquid food coloring (Schilling).

Three Plexiglas cups, holding approximately $120 \mathrm{cc}$ of tank water, were used as washing tanks. A terrycloth towel was folded to provide a cushion for the Ss and was saturated with tank water. Surgical gloves were worn when handling Ss or dyes.

\section{Procedures}

Surgical gloves were donned and all excess powder washed off
Three small cups were filled with tank water and placed nearby. A folded cloth provided a cushion for the $S$ and was saturated with tank water. A syringe with a 27-ga needle was prepared and filled with $0.05 \mathrm{cc}$ of the appropriate dye. An individual was netted, retained in the net, placed upon the cushion, and restrained with the net. $S$ was turned onto one side, and the needle was inserted almost parallel with the skin, at a slight angle, from rear to front about midway between the anal fin and the tail fin. The dye was injected as the needle was withdrawn; some seepage occurred, and the Ss seldom retained the full dose.

Immediately after injection, $S$ was placed into one of the three cups and left there until the water changed color, or approximately $30 \mathrm{sec}$. $S$ was then transferred into the second and third cups in like manner. After the water remained clear, $S$ was transferred into a portion of the tank separate from noninjected Ss and allowed to recover from the trauma. All injected Ss were placed together. (Ss normally remained inactive for 1 or $2 \mathrm{~h}$, during which time they refused food.) After $2 \mathrm{~h}$, Ss returned to their normal level of activity and were returned to the community tank. When $\mathrm{S}$ was returned to the community tank, the following observations were made: (1) Did S join the group? (2) Did S feed with the group? (3) Did S assume and maintain a position on or near the bottom of the tank? (4) Did the group ostracize S? (5) Did S exhibit any unusual behavior?

\section{RESULTS}

Table 1 shows the results of injection with each substance. The number of $\mathrm{Ss}$ injected with each substance varies according to the mortality rate of that substance. Toxic substances were eliminated when discovered, and no further injections were made with that substance. Thus, saffron red, gentian violet, toluidine blue, and Imferon were not used on large numbers of Ss and were deemed unsuitable.

Food coloring had the lowest mortality rate $(0)$, followed by sterile water $(1 / 10)$, methylene blue $(2 / 13)$, and green leaf shade (4/14). Of these, the longest lasting is methylene blue ( $7-15$ days for the first injection; 15-35 days on subsequent injections), followed by green leaf shade (7-15 days from the first injection; 7-30 days on subsequent injections). Food coloring had the shortest duration (1-2 days on any given injection).

Marked tissue damage was noted from all of the toxic substances (except Imferon), while no tissue damage was observed with methylene blue, green leaf shade, food coloring, or sterile water. 
Table 1

Substances Injected and Outcome of Injections

\begin{tabular}{|c|c|c|c|c|c|c|c|c|}
\hline Categories & $\begin{array}{l}\text { Methylene } \\
\text { Blue }\end{array}$ & $\begin{array}{l}\text { Green-Leaf } \\
\text { Shade } \\
\end{array}$ & $\begin{array}{l}\text { Saffron } \\
\text { Red }\end{array}$ & $\begin{array}{c}\text { Gentian } \\
\text { Violet }\end{array}$ & $\begin{array}{c}\text { Toluidine } \\
\text { Blue }\end{array}$ & $\begin{array}{l}\text { Food } \\
\text { Color }\end{array}$ & Imferon & $\begin{array}{l}\text { Sterile } \\
\mathrm{H}_{2} \mathrm{O}\end{array}$ \\
\hline Number injected & 13 & 14 & 3 & 2 & 2 & 4 & 2 & 10 \\
\hline $\begin{array}{l}\text { Number dead, first } \\
\text { injection }\end{array}$ & 1 & 1 & 2 & 2 & 0 & 0 & 2 & 1 \\
\hline $\begin{array}{l}\text { Number dead, } \\
\text { reinjected }\end{array}$ & 1 & 3 & 0 & 0 & 0 & 0 & 0 & 0 \\
\hline Total number dead & 2 & 4 & 2 & 2 & 2 & 0 & 2 & 1 \\
\hline $\begin{array}{l}\text { Range of duration } \\
\text { from first injection } \\
\text { in days }\end{array}$ & $7-15$ & $7-15$ & 4 & 3 & 3 & $1-2$ & 5 & n.a. \\
\hline $\begin{array}{l}\text { Range of duration of } \\
\text { reinjection in days }\end{array}$ & $15-35$ & $7-30$ & na. & n.a. & n.a. & $1-2$ & n.a. & n.a. \\
\hline Mobility impaired? & No & No & Yes & Yes & Yes & No & No & No \\
\hline $\begin{array}{l}\text { Marked tissue } \\
\text { damage }\end{array}$ & No & No & Yes & Yes & Yes & No & No & No \\
\hline $\begin{array}{l}\text { Individuality of } \\
\text { marking }\end{array}$ & $\begin{array}{l}\text { Good from } \\
\text { start }\end{array}$ & $\begin{array}{l}\text { Will change } \\
\text { dramatically } \\
\text { first } 48 \mathrm{~h} \text {, } \\
\text { then good }\end{array}$ & $\begin{array}{l}\text { Will change } \\
\text { dramatically } \\
\text { first } 48 \mathrm{~h} \text {, } \\
\text { then good }\end{array}$ & $\begin{array}{l}\text { Good, hard } \\
\text { to disting- } \\
\text { uish from } \\
\text { blue }\end{array}$ & Good & $\begin{array}{l}\text { Good over- } \\
\text { all color } 24- \\
48 \mathrm{~h} \text {; no dis- } \\
\text { tinct mark }\end{array}$ & $\begin{array}{l}\text { Not good } \\
\text { once bronze } \\
\text { color }\end{array}$ & $e^{\text {n.a. }}$ \\
\hline Ostracism & No & $\begin{array}{l}\text { Yes-one } \\
\text { overdose S } \\
\text { excreted } \\
\text { dye into } \\
\text { water }\end{array}$ & No & No & No & No & No & No \\
\hline Type of effect & $\begin{array}{l}\text { Distinct } \\
\text { mark } \\
\text { immedi- } \\
\text { ately }\end{array}$ & $\begin{array}{l}\text { Systematic } \\
\text { by } 48 \mathrm{~h} \text {, } \\
\text { then fades } \\
\text { to distinct } \\
\text { mark }\end{array}$ & $\begin{array}{l}\text { Systematic } \\
\text { by } 24 \mathrm{~h} \text {, } \\
\text { then fades } \\
\text { to distinct } \\
\text { mark }\end{array}$ & $\begin{array}{l}\text { Distinct } \\
\text { mark }\end{array}$ & $\begin{array}{l}\text { Distinct } \\
\text { mark }\end{array}$ & $\begin{array}{l}\text { Systematic } \\
\text { by } 24-48 \mathrm{~h} \\
\text { then fades }\end{array}$ & $\begin{array}{l}\text { Mark not } \\
\text { very good }\end{array}$ & n.a. \\
\hline Number reinjected & 12 & 10 & None & None & None & 4 & None & None \\
\hline Recommendation & $\begin{array}{l}\text { Highly } \\
\text { excellent } \\
\text { for all uses }\end{array}$ & $\begin{array}{l}\text { Good, } \\
\text { especially } \\
\text { for longer } \\
\text { studies }\end{array}$ & $\begin{array}{l}\text { Not recom- } \\
\text { mended, } \\
\text { toxic }\end{array}$ & $\begin{array}{l}\text { Not recom- } \\
\text { mended, } \\
\text { causes } \\
\text { marked tis- } \\
\text { sue damage, } \\
\text { death due } \\
\text { to fungal } \\
\text { infection }\end{array}$ & $\begin{array}{l}\text { Not recom- } \\
\text { mended }\end{array}$ & $\begin{array}{l}\text { Good for } \\
\text { short } \\
\text { studies, 24- } \\
48 \mathrm{~h}, \text { best } \\
\text { for vivid } \\
\text { color }\end{array}$ & $\begin{array}{l}\text { Not recom- } \\
\text { mended }\end{array}$ & $\begin{array}{l}\text { Con- } \\
\text { trol }\end{array}$ \\
\hline
\end{tabular}

Impairment of mobility was noted with saffron red and gentian violet, but not with any of the other substances.

The individuality of the marking, that is, the ease with which any given $\mathrm{S}$ could be distinguished from another $\mathrm{S}$ injected with the same dye, was good from the time of injection with methylene blue, while green leaf shade normally colored the entire fish for $48 \mathrm{~h}$, then faded, leaving a distinct mark. Food coloring colored the entire fish, but when it faded it did not leave a distinguishable mark.

\section{DISCUSSION}

The best results were obtained with methylene blue, particularly for longer usage. This dye has a low toxicity and remains distinct for some time. Green leaf shade was an excellent dye and had interesting effects, but is no longer easily obtainable. Surprising results were obtained with food coloring in that the entire fish became colored by dye, but the effect was rather short-lived.

This ability to mark, and even temporarily change, the color of fish opens many research areas. Examples of potential applicability are as follows: (1) The activities of al individual within a school could be observed, e.g., let $\mathrm{S}$ rejoin the group as reinforcement for some response. (2) Social facilitation can be more readily observed when schools of fish are used. (3) A group of fish can be kept in one tank and transferred individually to the test apparatus instead of having to keep Ss in isolated aquaria. (4) Individual interaction regarding courtship and aggression within a group can be more easily observed, and the effects of changed coloration upon dominance/territoriality may be observed.

\section{REFERENCES}

Braddock, J. C. The effect of residence on the dominance in fish, Platypoelius maculatus. Physiological Zoology, 1949, 22 , 151-169.

Keenleyside, M. H. A. Some aspects of the schooling behaviour of fish. Behaviour, 1955, 8, 183-248.

Martin, R. C., \& Deemer, B. A multiple-function swimway. Perceptual \& Motor Skills, 1971, 32, 775-780.

Shaw, E. Development of schooling behavior in fishes. Physiological Zoology, 1960, 33, 79-86. 